\title{
Life insurance :The alternative choice of savings for Thailand's Population Aging
}

\author{
Sivalap Sukpaiboonwat \\ Faculty of Economics, Srinakharinwirot University, Bangkok, Thailand
}

\begin{abstract}
The research problem is the demographic structure rapid change in Thailand .During the past 4 - 3decades have caused Thailand enters into an aging society since 2005is a population of 60years old, accounting for more than 10 percent of the total population. The predicting that Thailand will become aged society in 2021 and super aged society in the year .2031 If an individual savings is not enough, it may affect the livelihood that became a fiscal burden .This is an urgently important problem so Thai's government concerns this aspect and encourage Thai's people to increase savings especially voluntary savings in the third pillar. Under the theoretical savings system from the World Bank; the zero pillar is a non-contributory, the first pillar is a compulsory, the second pillar is a mandatory defined-contribution, the third pillar is a funded voluntary, the fourth pillar is a non-financial which informal support. Life insurance is one part of the third pillar which combines protection and savings.

The scope of this research is voluntary savings for retirement period. The method of analysis is qualitative and quantitative research .The study by using both secondary data from books, journal, website and related organizations and primary data from research questionnaire. The research finds many types of voluntary savings for retirement period; mutual fund, bank deposit, bond, cooperative stock, capital stock, debenture, life insurance, and etc. From 400 questionnaires, the first rank is the bank deposit with 32.13 percent, the second rank is life insurance with 27.25 percent and the third rank is mutual fund with 14.65 percent. This study confirms that life insurance is the alternative choice of savings for Thailand's population aging. This paper helps to understand the important life insurance in Thailand, which the long-term savings for Thailand's population aging in the future .
\end{abstract}

Keywords: Population aging, Voluntary savings, Life insurance 